\title{
Anopheles arabiensis in Sudan: a noticeable tolerance to urban polluted larval habitats associated with resistance to Temephos
}

Rasha S. Azrag ${ }^{1 *}$ and Babiker H. Mohammed ${ }^{1,2}$

\begin{abstract}
Background: It has been documented that unplanned urbanization leads to the exposure of members of the Anopheles vectors to a range of water pollution in urban settings. Many surveys from African and Asian countries reported the presence of Anopheles larvae in polluted urban habitats. The present study documents an obvious tolerance of the melanic and normal forms of Anopheles arabiensis to urban polluted larval habitats accompanied by resistance to Temephos larvicide.

Methods: A cross-sectional survey was carried out to inspect apparently polluted An. arabiensis larval habitats during the hot dry season of 2015. Larval specimens were collected from only apparently polluted habitats after visual inspection from 5 localities in Khartoum State. After morphological and molecular identification of random samples of larvae the magnitude of water pollution was determined using nine abiotic factors. The susceptibility status of $A n$. arabiensis larval forms from normal and polluted habitats to Temephos was tested using the WHO standard diagnostic concentration doses.
\end{abstract}

Results: Morphological and PCR analysis of anopheline larvae revealed the presence of An. arabiensis, a member of the Anopheles gambiae complex. Seven out of 9 physiochemical parameters showed higher concentrations in polluted larval habitats in comparison to control site. Anopheles arabiensis larvae were found in water bodies characterized by high mean of conductivity (1857.8 $\pm 443.3 \mathrm{uS} / \mathrm{cm})$, turbidity $(189.4 \pm 69.1 \mathrm{NTU})$ and nitrate $(19.7 \pm 16.7 \mathrm{mg} / \mathrm{l})$. The range of mortality rates of An. arabiensis larvae collected from polluted habitats in comparison to An. arabiensis larvae collected from non-polluted habitats was 6.7-64\% $\left(\mathrm{LD}_{50}=1.682\right)$ and $67.6-96 \%\left(\mathrm{LD}_{50}=0.806\right)$, respectively.

Conclusions: The present study reveals that minor populations of An. arabiensis larval forms are adapted to breed in polluted urban habitats, which further influenced susceptibility to Temephos, especially for the melanic larval forms. This could have further implications on the biology of the malaria vector and on the transmission and epidemiology of urban malaria in Sudan.

Keywords: Pollution, Larval habitats, Anopheles arabiensis, Sudan

\footnotetext{
*Correspondence: razrag@hotmail.com

${ }^{1}$ Department of Zoology, Faculty of Science, University of Khartoum,

Khartoum, Sudan

Full list of author information is available at the end of the article
} 


\section{Background}

During the past 10 years many studies have stated that Anopheles species were adapted to polluted habitats in urban settings, the majority from African countries. Anopheles gambiae sensu stricto (s.s.) in urban settings in Nigeria are adapting to a wide range of water pollution [1].

In urban cities in Ghana, An. gambiae was found in polluted aquatic habitats and this, coupled with occurrence of insecticide resistance, is alarming [2]. In Yaoundé, Cameroon, the presence of An. gambiae in organically polluted sites has been confirmed [3]. Other studies such as in Pakistan and Sri Lanka indicated the adaptation of Anopheles gambiae sensu lato (s.l.) and Anopheles culicifacies to organically polluted water habitats $[4,5]$ and reported that rapid, unplanned urbanization is considered to favour adaptation of anophelines to various xenobiotics and the expansion of their niche to polluted habitats. Anopheles gambiae complex, which includes the major vectors in Africa, has the capacity to exploit different kinds of habitat that are created either directly or indirectly by humans. This is evidenced by its wide geographical distribution and its occurrence in a variety of micro- and macro-environmental conditions throughout tropical Africa, and that larvae were found in habitats organically polluted by rotting vegetation, human faeces, or oil $[2,6,7]$.

Anopheles arabiensis, a sibling species of the An. gambiae complex, is a predominant malaria vector all over Sudan, covering arid and semi-arid areas of the country. It is the only malaria vector encountered in Khartoum State [8], the capital of Sudan, which have long been Sudan's primary industrial, commercial and manufacturing hubs with very poor infrastructure that has many environmental consequences [9]. The present study documents, the presence of $A n$. arabiensis larvae in polluted habitats in urban Khartoum, central Sudan, which further influenced its susceptibility to insecticides.

\section{Methods \\ Study area}

This study was carried out in Khartoum in central Sudan, at the confluence of the White Nile and Blue Nile, $\left(31.5-34^{\circ} \mathrm{E}\right.$ and $\left.15-16^{\circ} \mathrm{N}\right)$, over $250 \mathrm{~km}$ and a total area of 20,736 sq km (Fig. 1). According to the Sudan Meteorological Authority (SMA), the temperatures range between 25 and $40{ }^{\circ} \mathrm{C}$ during the months April to June and between 20 and $35{ }^{\circ} \mathrm{C}$ during July to October. Temperatures fall during the winter period between November and March to $15-25^{\circ} \mathrm{C}$.

Most of Khartoum State falls within the semi-desert climatic zone while the northern part falls within the desert climatic zone. The State is prevailed with a hot to very hot rainy season during the summer and warm to cold dry season during the winter. Rainfall ranges between 100 and $200 \mathrm{~mm}$ in northeastern parts, $200-300 \mathrm{~mm}$ in southern parts and 10,100 $\mathrm{mm}$ in the northwestern parts.

Khartoum State has a population of 5,271,321, according to the Census conducted in 2008 by the Central Bureau of Statistics [10]. Khartoum's drainage and sanitation systems are in poor condition. Only $28 \%$ of Khartoum is connected to a sewage system, and most residents use pit latrines and other basic systems such as septic tanks and siphon wells.

\section{Larval surveillance}

Two cross-sectional larval surveillance surveys were carried out in 5 localities in Khartoum State: Khartoum, East Nile, Jubal Aulia, Khartoum North, and Omdurman. The first survey was carried out during the hot dry season from February to April 2015 and was designed to study the possibility of Anopheles larvae to breed in polluted aquatic habitats. The second surveillance was conducted during the late rainy season from September to November 2015 to examine the susceptibility of $A n$. arabiensis found in polluted water bodies to Temephos larvicide.

\section{Survey 1}

Larvae specimens were collected from only apparently polluted habitats after visual inspections. According to [3, 6], polluted larval habitats of An. gambiae s.l. are: "semi-permanent water collections containing domestic waste or organic products in decomposition that could be invaded by moisture and/or algae". The expectation of polluted larval habitats in urban areas came after: visual inspection (colour and odour); presence near drainage system; presence near industrial areas presence near effluent from local houses and presence near university campus and military camps.

A handheld global positioning system (GPS) was used to determine and record the precise grid co-ordinates of the positive larval habitats. Samples of Anopheles larvae present in suspected polluted habitats were collected using standard dipping methods and preserved in $80 \%$ ethanol in small glass bottles with full labels. Water samples from each site were collected concurrently to study physiochemical parameters and preserved in clean plastic bottles $(600 \mathrm{ml})$.

\section{Survey 2}

Mosquito larvae were collected from 4 localities in Khartoum State: Khartoum, Khartoum North, East Nile, and Jabal Awlia, to determine susceptibility of An. arabiensis larvae in polluted larval bodies to Temephos larvicide. Samples were collected from two types of habitats: 


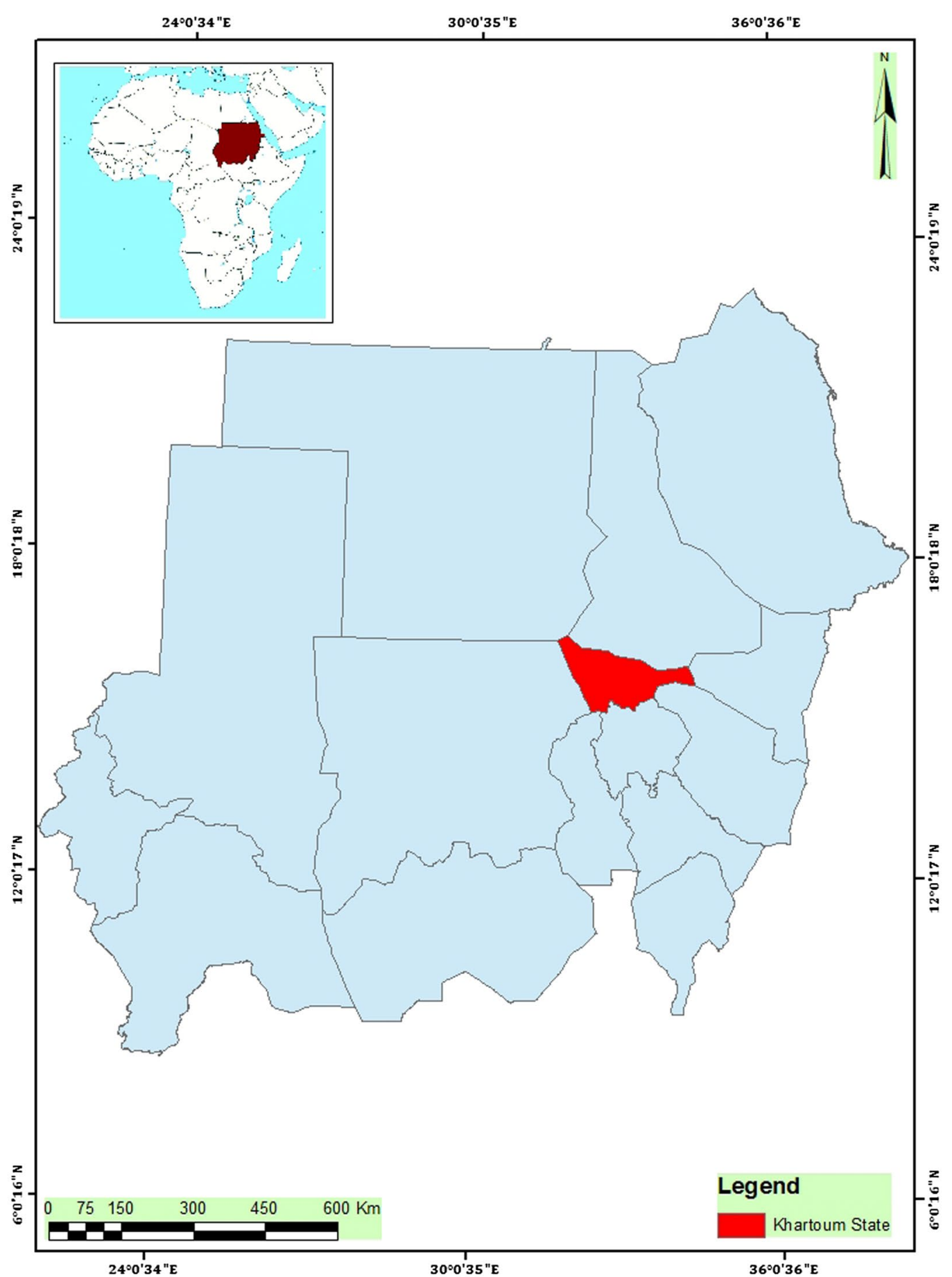

Fig. 1 Geographic location of Khartoum state

- Polluted Anopheles species habitats that represented the positive Anopheles larvae habitats identified during Survey 1.

- Non-polluted Anopheles species larval habitats in agricultural areas within urban Khartoum State.

\section{Collection, preservation and identification methods}

Anopheles larvae were sampled using standard dipping method; from each breeding site, 10 dips were taken with a standard 300-ml dipper according to [11]. Larvae were preserved in $80 \%$ ethanol in glass bottles. In the 
laboratory, larvae were identified morphologically using [12] and molecularly using species-specific identification according to [13]. Melanic and normal forms were classified according to [14].

\section{Physicochemical analysis of water samples}

Water samples were collected from each visually polluted larval habitat in 600-ml clean plastic bottles. To study the magnitude of water pollution at the breeding sites eight abiotic factors were determined, including colour, odour, $\mathrm{pH}$, conductivity, total dissolved solids, turbidity, oil and nitrate. Water pollution associated with heavy metals was determined for three heavy metals $(\mathrm{Cu}, \mathrm{Pb}$, $\mathrm{Fe}$ ), which were chosen as they were previously studied in An. gambiae s.s. polluted larval habitats [1]. Water samples were analysed in the Central Laboratory, Chemistry Department, Khartoum University. $\mathrm{pH}$, conductivity and total dissolved solids (TDS) were analysed using pH 315i/SET, NO: 2A10-1012 and Cond 315i/SET, NO: 2C10-001, Germany, and turbidity was measured using Palintest: Turbimerer, PT 0900513197, UK. Heavy metals were determined using atomic absorption spectrophotometry at the Central Laboratory, Chemistry Department, Khartoum University. Physiochemical parameters from apparently polluted larval habitats were compared to physiochemical parameters of a control larval habitat (an irrigation canal at an agricultural area within Khartoum State).

\section{Bioassay tests}

The susceptibility bioassays were performed according to [15]. Twenty-five late third to early fourth-instar larvae of An. arabiensis were laboratory assayed for sensitivity to Temephos larvicide using four diagnostic concentrations; $0.005,0.025,0.125$, and $0.625 \mathrm{mg} / \mathrm{l}$. The average temperature of the water was $25{ }^{\circ} \mathrm{C}$. Each concentration was replicated three times. After a period of $24 \mathrm{~h}$, mortality counts were performed. Control trials were performed under same conditions.

\section{Data analysis}

Data were analysed using SPSS version 15.0. Descriptive statistics were used. The relationship between habitats variables and presence of anophelines in polluted water was tested using correlation. Only variables with $\mathrm{P}$ values $<0.05$ were considered. The results of the insecticide susceptibility tests were analysed for dose/response relationship using regression probit analysis [16]. The 50\% lethal concentration or $\mathrm{LC}_{50}$ value is commonly accepted as the basis for comparison in the investigation of relative toxicities among insecticides used.

\section{Results}

\section{Identification of Anopheles larvae}

A total of 377 larvae were collected during Survey 1. Random samples of larvae were reared in the laboratory and all larvae successfully completed their development and emerged as adults. All samples were identified as $A n$. gambiae complex and all PCR products of the amplification of intergenic spacer region (IGS) of ribosomal DNA (rDNA) of larvae specimens showed the diagnostic fragments of 315 base pairs that identify An. arabiensis. Normal and melanic larval forms were identified from all types of larval habitats with a noticeable increase of the melanic in polluted larval habitats described below.

\section{Types of polluted larval habitats}

Anopheles arabiensis larvae were collected from 17 polluted larval habitats that were disproportionately divided between the 5 localities. Most prevalent types of polluted larval habitats were drains of concrete sewers (39\%) followed by pools created from sewage canal and industrial effluent, both constituted $17 \%$ and manholes and drainage canal both constituted $11 \%$. Types and nature of polluted larval habitats are shown in Fig. 2.

Khartoum North and East Nile localities both represented $56 \%$ of the total positive polluted larval habitats, followed by Omdurman 17\%, Khartoum 16, and 11\% Jabal Awlia.

\section{Larval density per type of habitat}

Polluted larval habitats were classified into either semipermanent (available for 3 months) and permanent habitats (available for more than 3 months) without any type of temporary habitats. Two types of polluted habitats were noticed, permanent and semi-permanent: $61 \%$ of polluted habitats were permanent and $39 \%$ were semipermanent. Highest mean density/dip of An. arabiensis larvae was recorded in semi-permanent habitats (2.2/dip) in comparison to permanent habitats (1.98/dip) (Fig. 3).

\section{Physicochemical parameters of polluted larval habitat}

Table 1 summarizes the polluted habitats of An. arabiensis in Khartoum State, their positions, types and physiochemical descriptions. The $\mathrm{pH}$ ranged from 6.8 to 8.0 in polluted habitats, which was 1.1-fold higher in comparison to control site. The highest $\mathrm{pH}$ was observed in East Nile in Eilafun camp (8.0) while the lowest one was recorded in Khartoum North in Elsababi (6.8). Khartoum North showed highest mean of conductivity in Khartoum North-Industrial Area $(6650 \mathrm{uS} / \mathrm{cm})$ and the lowest was observed in Khartoum North-Wad-ELsaaeh $(313 \mathrm{uS} / \mathrm{cm})$. The mean of turbidity (NTU) in polluted habitats was $(189.4 \pm 69.1)$, 

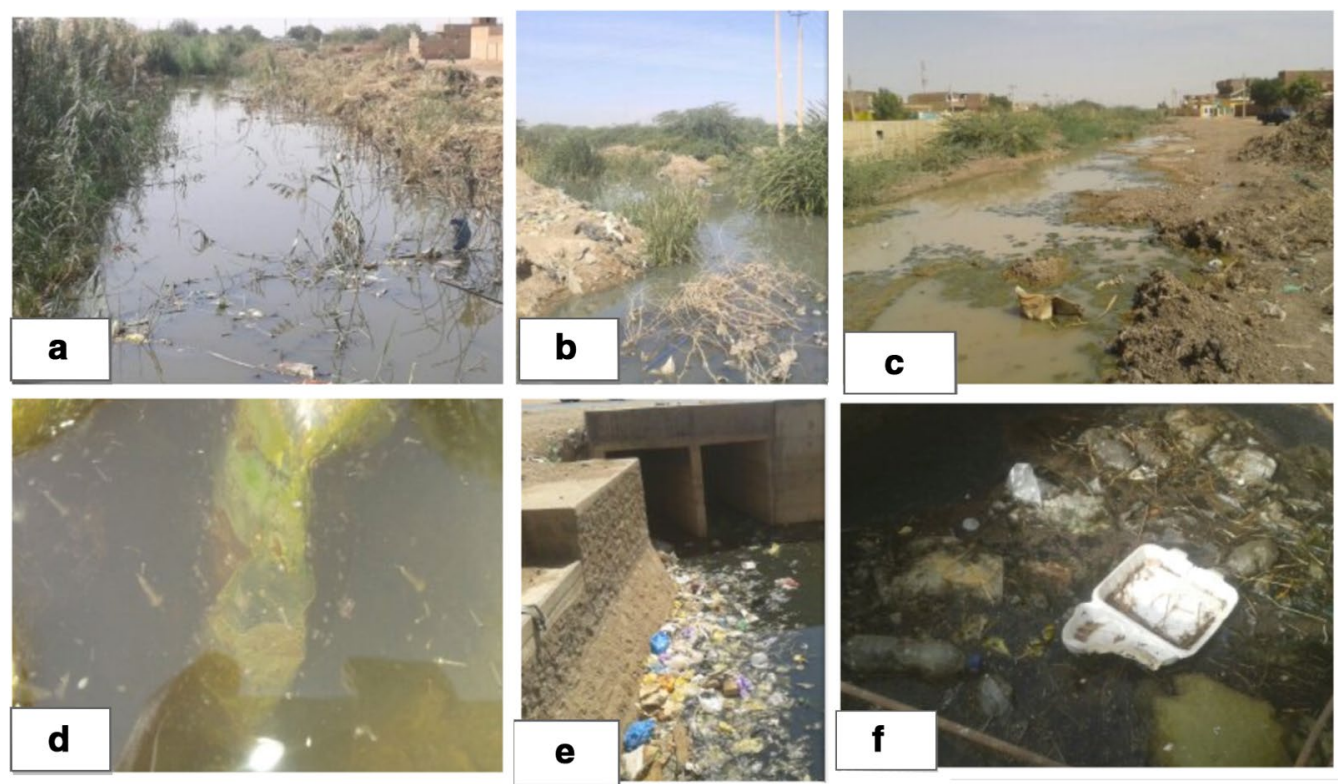

Fig. 2 Types of polluted habitats in Khartoum State. a main canal of plant treatment; b junction of tributaries of main sewage canal; c pools created from leakage of main sewage canal; $\mathbf{d}$ polluted pond; $\mathbf{e}$ a culvert on a drainage canal; $\mathbf{f}$ manhole sewers

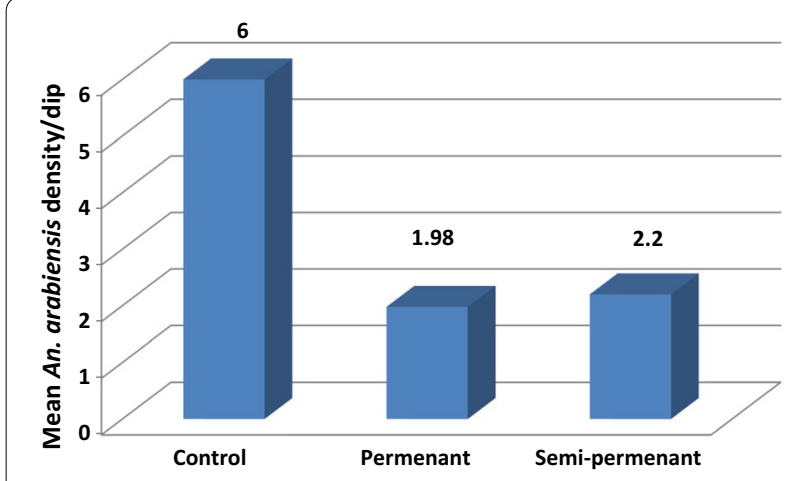

Fig. 3 Density of Anopheles arabiensis in polluted larval habitats in comparison to control site during the hot dry season

which was 52.6-fold in comparison to control site (3.6). East Nile -Hag Yousif (Shiglah) registered the highest NTU (1012) and the lowest was observed in East NileEilafun military camp (2.9 NTU).

The mean of oil in polluted habitats was $(0.06 \pm 0.02 \mathrm{mg} / \mathrm{l})$ which was 6.7 times higher in comparison to control site $(0.009 \mathrm{mg} / \mathrm{l})$. However, very high concentration of oil was recorded in East Nile-Eilafun military camp $(0.4 \mathrm{mg} / \mathrm{l})$. The mean of nitrate in polluted habitats was $(19.7 \pm 16.7)$ which was 4.6 times higher in comparison to control site (4.3). The highest concentration of nitrate was observed in Jebel AwliaAbu Adam (303 mg/l).
The mean of Fe $(\mathrm{mg} / \mathrm{l})$ in polluted larval habitats was $(0.3 \pm 0.1)$ in comparison to $0 \mathrm{Fe} \mathrm{mg} / \mathrm{l}$ in control site. Jebel Awlia-Block $(1+3)$ showed highest mean of Fe $(2.0 \mathrm{mg} / \mathrm{l})$. Regarding $\mathrm{Cu}(\mathrm{mg} / \mathrm{l})$ in polluted habitats the mean was $(0.004 \pm 0.001)$ which was fivefold lower in comparison to control site and was not detected in Khartoum North-Kober and East Nile-Eilafun camp. Similarly, concentration of $\mathrm{Pb}$ in polluted habitats was $(0.02 \pm 0.01 \mathrm{mg} / \mathrm{l})$ which was 3.5 times lower in comparison to control site. Table 2 shows types and geographical locations of polluted larval habitats.

\section{Physicochemical characteristics of polluted larval habitats per locality}

When data of physiochemical parameters of polluted habitats were analysed according to localities, the average larval density per dip per locality was higher in East Nile (3.1 larvae/dip) followed by Khartoum (2 larvae/dip) and Jabal Awlia (1.5 larvae/dip). The $\mathrm{pH}$ readings of the water samples across all localities were higher than the readings of control site. The conductivity recorded across all localities was sixfold higher than the control site. However, Khartoum, Jabal Awlia and Khartoum North were more than ninefold higher than control site (2756, 2158.5, 2101.8 and $216 \mathrm{uS} / \mathrm{cm}$, respectively) (Table 3 ).

Jabal Awlia was characterized as having a highest mean of nitrate (156.2 NTU) and was 36-fold higher than the value of nitrate recorded in control site (4.3 NTU). Jabal 


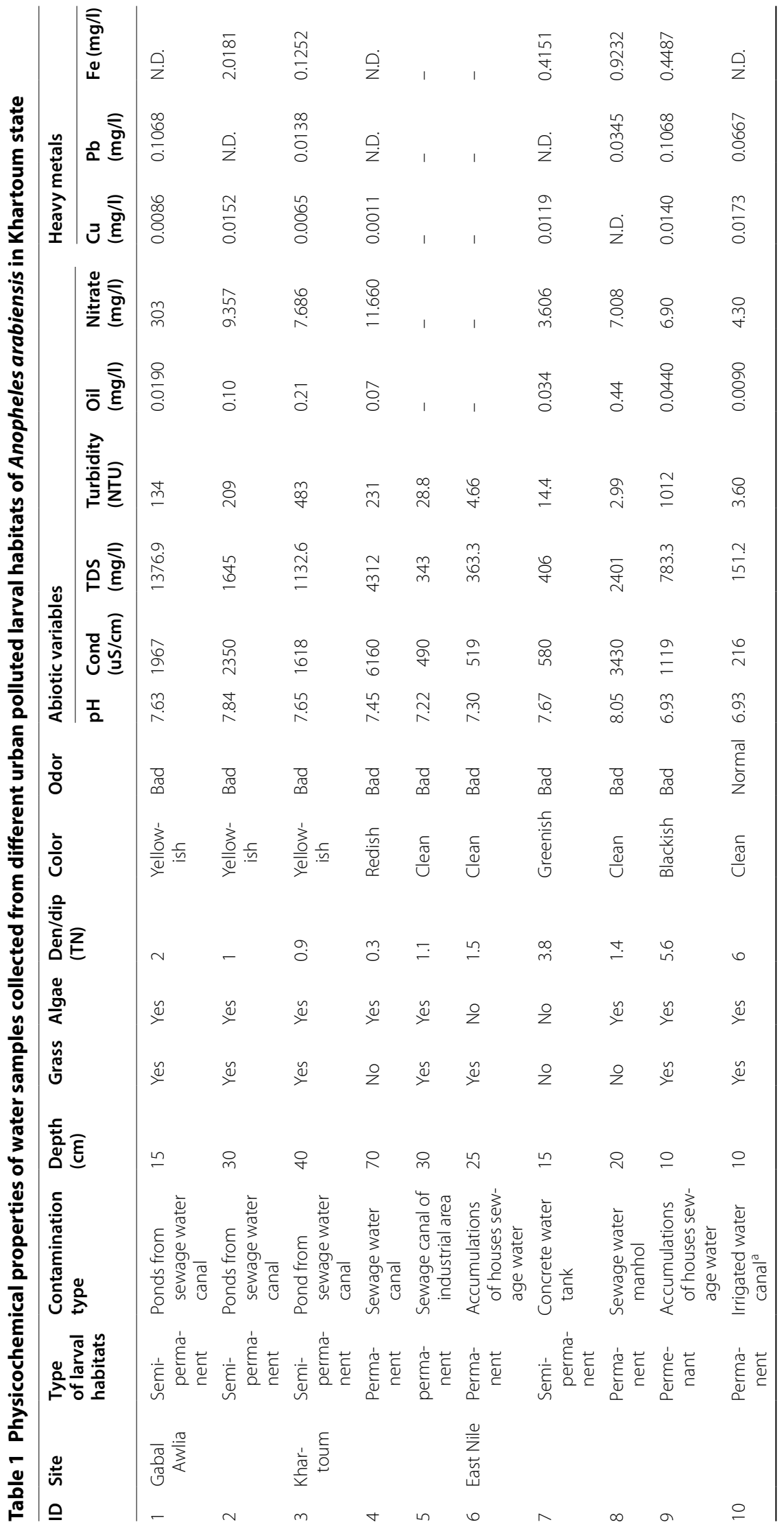




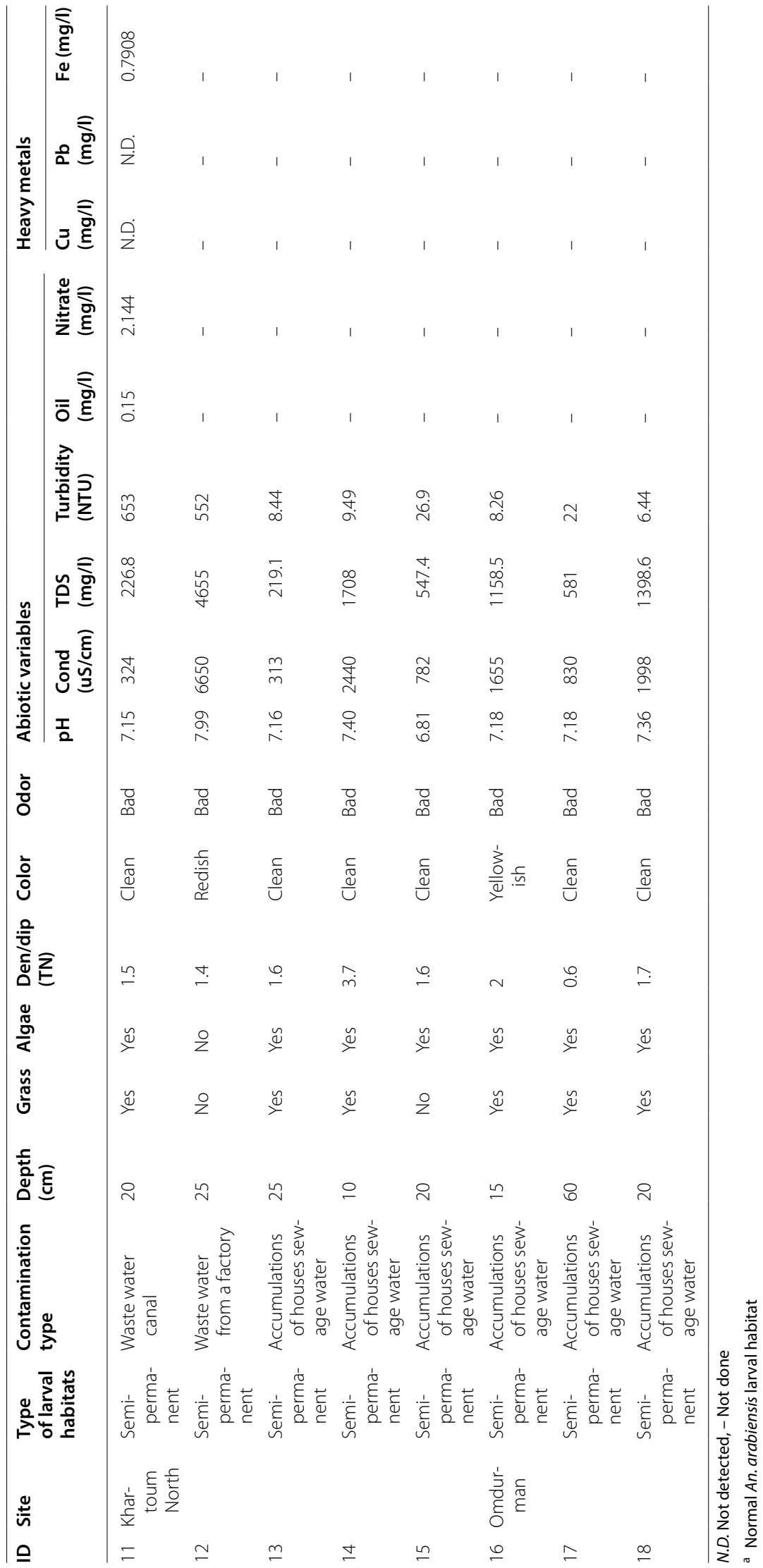


Table 2 Types and geographical positions of positive polluted An. arabiensis larval habitats in Khartoum state

\begin{tabular}{lllll}
\hline Locality & Site & GPS position & Type of larval habitats & Permanent/semi-permanent \\
\hline East Nile & Elshiglah & $15^{\circ} 38.547^{\prime} \mathrm{N}, 32^{\circ} 37.545^{\prime} \mathrm{E}$ & Drainage canal (Khor) & Permanent \\
& Eldoha & $15^{\circ} 37.083^{\prime} \mathrm{N}, 32^{\circ} 35.873^{\prime} \mathrm{E}$ & Drains of concrete sewer & Permanent \\
& Eilafun Hospital & $15^{\circ} 25.287^{\prime} \mathrm{N}, 32^{\circ} 43.848^{\prime} \mathrm{E}$ & Manhole & Semi-permanent \\
& Eilafun Camp & $15^{\circ} 24.884^{\prime} \mathrm{N}, 32^{\circ} 43.775^{\prime} \mathrm{E}$ & Manhole & Permanent \\
& Selate (Control) & $15^{\circ} 34.622^{\prime} \mathrm{N}, 32^{\circ} 39.908^{\prime} \mathrm{E}$ & Irrigated canal (Abueshreen) & Permanent (irrigated project) \\
Khartoum North & Kober & $15^{\circ} 38.057^{\prime} \mathrm{N}, 32^{\circ} 32.855^{\prime} \mathrm{E}$ & Drains of concrete sewer & Permanent \\
& Indust-area & $15^{\circ} 38.120^{\prime} \mathrm{N}, 32^{\circ} 33.075^{\prime} \mathrm{E}$ & Industrial effluents & Permanent \\
& Elsababi & $15^{\circ} 37.981^{\prime} \mathrm{N}, 32^{\circ} 31.774^{\prime} \mathrm{E}$ & Drainage canal (Khor) & Semi-permanent \\
& Wadelsaeh & $15^{\circ} 38.511^{\prime} \mathrm{N}, 32^{\circ} 30.797^{\prime} \mathrm{E}$ & Drains of concrete sewer & Permanent \\
Khartoum & Hilatkhogali & $15^{\circ} 37.855^{\prime} \mathrm{N}, 32^{\circ} 30.944^{\prime} \mathrm{E}$ & Drains of concrete sewer & Permanent \\
& Industrial area & $15^{\circ} 35.215^{\prime} \mathrm{N}, 32^{\circ} 30.573^{\prime} \mathrm{E}$ & Industrial effluents & Semi-permanent \\
& Elrimalah & $15^{\circ} 33.574^{\prime} \mathrm{N}, 32^{\circ} 30.361^{\prime} \mathrm{E}$ & Industrial effluents & Permanent \\
Omdurman & Eldubaseen & $15^{\circ} 30.483^{\prime} \mathrm{N}, 32^{\circ} 29.745^{\prime} \mathrm{E}$ & Pools of sewage canal & Semi-permanent \\
& Baitelmal & $15^{\circ} 38.976^{\prime} \mathrm{N}, 32^{\circ} 30.226^{\prime} \mathrm{E}$ & Drains of concrete sewer & Permanent \\
Jabel Awlia & Elhigrah & $15^{\circ} 39.441^{\prime} \mathrm{N}, 32^{\circ} 29.905^{\prime} \mathrm{E}$ & Drains of concrete sewer & Semi-permanent \\
& Elmulazmeen & $15^{\circ} 37.898^{\prime} \mathrm{N}, 32^{\circ} 29.473^{\prime} \mathrm{E}$ & Drains of concrete sewer & Permanent \\
& Abu Adam & $15^{\circ} 30.612^{\prime} \mathrm{N}, 32^{\circ} 29.937^{\prime} \mathrm{E}$ & Pools of sewage canal & Semi-permanent \\
\hline
\end{tabular}

Table 3 Physicochemical parameters per locality

\begin{tabular}{|c|c|c|c|c|c|c|c|c|c|c|}
\hline Site & $\begin{array}{l}\text { Density } \\
\text { per dip }\end{array}$ & $\mathrm{PH}$ & $\begin{array}{l}\text { Conductivity } \\
\text { (uS/cm) }\end{array}$ & TDS (Mg/l) & Turbidity (NTU) & Nitrate (mg/l) & Oil (mg/l) & $\mathrm{Cu}(\mathrm{mg} / \mathrm{l})$ & $\mathrm{Pb}(\mathrm{mg} / \mathrm{l})$ & $\mathrm{Fe}(\mathrm{mg} / \mathrm{l})$ \\
\hline East Nile & 3.1 & 7.5 & 1412 & 988.4 & 258.5 & 5.84 & 0.173 & 0.0086 & 0.0471 & 0.595 \\
\hline Jabal Awlia & 1.5 & 7.7 & 2158.5 & 1511 & 171.5 & 156.2 & 0.0595 & 0.0119 & 0.0534 & 1.009 \\
\hline Khartoum North & 0.8 & 7.3 & 2101.8 & 1471.3 & 250 & 2.14 & 0.15 & - & - & 0.7908 \\
\hline Khartoum & 2 & 7.4 & 2756 & 1929.2 & 247.6 & 9.67 & 0.14 & 0.0038 & 0.0069 & 0.0626 \\
\hline Omdurman & 1.4 & 7.2 & 1494.3 & 1046.1 & 12.2 & - & - & - & - & - \\
\hline Control & 6 & 6.9 & 216 & 151.2 & 3.6 & 4.3 & 0.009 & 0.0173 & 0.0667 & ND \\
\hline
\end{tabular}

ND not done

Awlia recorded highest level of Fe $(1.009 \mathrm{mg} / \mathrm{l})$ in comparison to other localities.

\section{Temephos bioassay}

Three different bioassay tests were done, each with three replicates along with control tests. The first and second tests were conducted to evaluate susceptibility status of the melanic $(\mathrm{M})$ and normal $(\mathrm{N})$ forms collected from non-polluted habitats with a total of 358 and 374 larvae, respectively. The third test was done to evaluate susceptibility status of An. arabiensis larvae found in polluted habitats and included 373 larvae that were collected from the polluted sites identified in Survey 1.

Table 4 shows $100 \%$ mortality rates for An. arabiensis $\mathrm{M}$, when exposed to 0.125 and $0.625 \mathrm{mg} / \mathrm{l}$ concentrations of Temephos. However, lower concentrations showed that lower mortality rates ranged between 87.3 and $16.2 \%$. Anopheles arabiensis $\mathrm{N}$ larvae showed similar mortality rates for $0.125,0.625$ and $0.025 \mathrm{mg} / \mathrm{l}$ concentrations of Temephos, with mortality rates ranged between 100 and $96 \%$. However, lower mortality rates (67.6\%) were reported for $0.005 \mathrm{mg} / \mathrm{l}$ concentration. One-hundred percent mortality rates were reported for $A n$. arabiensis larvae collected from polluted habitats for 0.125 and $0.625 \mathrm{mg} / \mathrm{l}$ concentrations of Temephos. Lower mortality rates ranging between 64 and $6.7 \%$ were reported for 0.025 and $0.005 \mathrm{mg} / \mathrm{l}$ concentrations, respectively.

\section{Calculations of $\mathrm{LD}_{50}$ and $\mathrm{LD}_{95}$}

Higher $\mathrm{LD}_{50}$ to Temephos was reported with $A n$. arabiensis M $(1.369 \mathrm{mg} / \mathrm{l})$ in comparison to An. arabiensis $\mathrm{N}(0.806 \mathrm{mg} / \mathrm{l})$. Regarding An. arabiensis collected from polluted habitats $\mathrm{LD}_{50}$ was $1.682 \mathrm{mg} / \mathrm{l}$ and $\mathrm{LD}_{95}$ was $2.785 \mathrm{mg}$, which indicates resistance to Temephos (Table 5). 
Table 4 Mortality rates of An. arabiensis forms exposed to different concentrations of Temephos insecticide

\begin{tabular}{|c|c|c|c|c|c|c|c|c|c|}
\hline \multirow{2}{*}{$\begin{array}{l}\text { Concentrations } \\
(\mathrm{mg} / \mathrm{l})\end{array}$} & \multicolumn{3}{|c|}{ An. arabiensis melanic form (M) } & \multicolumn{3}{|c|}{ An. arabiensis normal form (N) } & \multicolumn{3}{|c|}{ An. arabiensis from polluted sites } \\
\hline & $\begin{array}{l}\text { Number } \\
\text { exposed }\end{array}$ & Number dead & Mortality \% & $\begin{array}{l}\text { Number } \\
\text { exposed }\end{array}$ & Number dead & Mortality \% & $\begin{array}{l}\text { Number } \\
\text { exposed }\end{array}$ & Number dead & Mortality \% \\
\hline 0.005 & 74 & 12 & 16.2 & 74 & 50 & 67.6 & 75 & 5 & 6.7 \\
\hline 0.025 & 71 & 62 & 87.3 & 75 & 72 & 96 & 75 & 48 & 64 \\
\hline 0.125 & 68 & 68 & 100 & 75 & 75 & 100 & 74 & 74 & 100 \\
\hline 0.625 & 70 & 70 & 100 & 75 & 75 & 100 & 75 & 75 & 100 \\
\hline
\end{tabular}

Table 5 Lethal concentration $50 \%\left(L_{50}\right)$ and $95 \%\left(L_{95}\right)$ of An. arabiensis larval forms exposed to WHO discriminative doses of Temephos insecticides

\begin{tabular}{|c|c|c|c|}
\hline Species & $\begin{array}{l}95 \% \text { confidence limits LD } \\
\text { up (lower- } \\
\text { upper) }\end{array}$ & $\begin{array}{l}95 \% \text { confidence limits } \mathrm{LD}_{95} \text { (lower- } \\
\text { upper) }\end{array}$ & $X^{2} P$ value \\
\hline An. arabiensis melanic form (M) & $1.369(1.263-1.481)$ & $2.287(2.053-2.653)$ & 0.742 \\
\hline An. arabiensis normal form (N) & $0.806(0.612-0.941)$ & $1.798(1.547-2.337)$ & 0.778 \\
\hline An. arabiensis in polluted habitats & $1.682(1.557-1.805)$ & $2.785(2.535-3.160)$ & 0.072 \\
\hline
\end{tabular}

$P$ value $\leq 0.05$ considered as significant

\section{Discussion}

Until recently, urban development was generally believed to reduce the risk of vector breeding, and thus malaria transmission. However, millions of clinical episodes of malaria occur annually in urban areas, indicating that the epidemiology of this disease is changing $[17,18]$. The findings of the present study, together with other studies on other anopheline mosquitoes, indicate a change of $A n$. arabiensis breeding requirements in urban settings. This is in line with many studies which stated that Anopheles mosquitoes have adapted to new breeding sites created by urbanization [19]. Studies conducted in Accra, Ghana and Dar es Salaam in Tanzania, revealed the presence of An. gambiae s.l. in organically polluted water habitats, sewage ponds and in swamps extremely polluted with organic matter $[4,7]$.

Khartoum State in Central Sudan had a unique Khartoum Malaria-Free Initiative (KMFI), which was launched in 2002 by the State and the Federal Ministry of Health, in collaboration with WHO. The core intervention for KMFI was larval control through weekly application of Temephos and environmental management [20]. The continuous application of Temephos larvicide for more than 13 years might explain the development of resistance to Temephos. Anopheles arabiensis from polluted habitats was more tolerant to Temephos compared to $A n$. arabiensis from non polluted habitats. This finding is in line with Kabula et al. [2] who suggested that the adaptation of An. gambiae s.s. to breed in polluted water may be influenced by their insecticide resistance status and vice versa. It is more likely that resistant gravid female choose the available polluted water as a last chance to lay its eggs when they have no choice during the hot dry season to find an alternative habitat which require more flying during an extreme harsh environmental condition. Aboud et al. [14] reported that the haplotype diversity within melanic populations of An. arabiensis was higher than within normal populations and better adapted to hot and arid environments. A high level of genetic diversity is often beneficial to a species as it provides more opportunities for adaptation when a species environment change and might explain the increased tolerance of the melanic form to Temephos insecticide.

The mean level of conductivity reported in this study increased 8.6 times compared to control site. Similar findings was obtained by Tene Fossog et al. [6] in Douala, Cameroon, for conductivity in non-polluted and polluted sites and by Awolola et al. [1] in Lagos, Nigeria. However, in Yaoundé, Cameroon, Antonio-Nkondjio et al. [3] recorded lower values of conductivity in rural and urban habitats. In the present study, the turbidity levels were similar to with the result recorded by Awolola et al. [1]. The simple definition of 'turbidity', which favours Anopheles larvae in a habitat might not be precise enough. This is because water which is turbid from particles not nutritious for Anopheles larvae could disfavour the growth and development of larvae and can be considered a limiting factor [21], while water turbid from food particles represents a very suitable habitat and may be useful for larval development. Some studies showed that An. arabiensis and An. gambiae s.s. larvae were associated with highly turbid water, with algae and little or no 
aquatic vegetation, while other studies recorded presence of algae and vegetation as limiting factors [22, 23]. This study reported that all water bodies (permenant or semi permenent) are potential larval habitats and help maintaing the vector populations during the hot dry season. [24] reported that permanence of a habitat had no significant influence on larval productivity and all potential breeding sites need to be considered as source of malaria risk at any time of the year.

The study confirmed the presence of oil in polluted water but the values was lower compared to the values recorded by Awolola et al. [1] in Lagos, Nigeria, who found that the level of the three heavy metals $(\mathrm{Fe}, \mathrm{Cu}, \mathrm{Pb})$ was more than twofold higher than those obtained from the control site. However, in this study concentrations of $\mathrm{Pb}(\mathrm{mg} / \mathrm{l})$ and $\mathrm{Cu}(\mathrm{mg} / \mathrm{l})$ were less by at least three times in comparison to the control site. The present study found that the mean of nitrate was 4.6 times compared to control site.

The findings of the present study together with other studies from sub-Saharan Africa and other parts of the world, indicates that An. gambiae complex is adapting to a wide range of water pollution in urban settings. Anopheles larvae are not restricted to clearly defined habitats. Therefore, all water bodies in an urban environment should be considered potential breeding places and must be a target for larval control. Further studies are need to be shown over time, during different seasons, in respect to other positive habitats from the total found in the area to estimate the extent of this adaptation in the targeted area.

\section{Conclusions}

The present study documents the presence of minor populations of $A n$. arabiensis larvae in polluted urban habitats in Khartoum state which could have further implications on the biology of malaria vector and the epidemiology of urban malaria in Sudan. The study highlights the need for more precise definitions for larval habitats of malaria vectors.

\section{Abbreviations}

GPS: global positioning system; KMFI: Khartoum malaria free initiative; LC: lethal concentration; LSM: larval source management; mg/l: milligram per litre; ml: millilitre; s.l.: sensu lato; s.s.: sensu stricto; TDS: total dissolved solids.

\section{Authors' contributions}

RSA Designed the present study, participated in the field work, contributed in physcio-chemical and data analyses and wrote the first draft of the manuscript. BHM carried on the field work, contributed to the physcio-chemical analysis and conducted laboratory bioassays and contributed to the writing of the manuscript. Both authors read and approved the final manuscript.

\section{Author details}

${ }^{1}$ Department of Zoology, Faculty of Science, University of Khartoum, Khartoum, Sudan. ${ }^{2}$ Ministry of Health, Khartoum State, Malaria Control Department, Vector Surviellance Unit, Khartoum, Sudan.

\section{Acknowledgements and Funding}

We would like to acknowledge the staff members of the Central Laboratory at the Faculty of Science, University of Khartoum for physcio-chemical analysis of water samples. Many thanks to Mr. Jihad Eltahir from Prof. Elgaddal Research and Training center at Sinnar state for providing the WHO kits for Bioassays.

\section{Competing interests}

The authors declare that they have no competing interests.

\section{Availability of data and materials}

Data represented include most of the raw data. However, a complete data set will be ready for submission to the Dryad Digital Depository (http://datadryad. org/). l'll upload it as data as soon you accept our paper and confirm that our submission conforms to MJ submission requirements.

\section{Consent for publication}

Not applicable.

Ethics approval and consent to participate

The study does not involve human or animal subjects.

\section{Publisher's Note}

Springer Nature remains neutral with regard to jurisdictional claims in published maps and institutional affiliations.

Received: 9 October 2017 Accepted: 7 May 2018

Published online: 18 May 2018

\section{References}

1. Awolola TS, Oduola AO, Obansa JB, Chukwurar NJ, Unyimadu JP. Anopheles gambiae s.s. breeding in polluted water bodies in urban Lagos, southwestern Nigeria. J Vector Borne Dis. 2007:44:241-4.

2. Kabula BI, Attah PK, Wilson MD, Boakye DA. Characterization of Anopheles gambiae s.l. and insecticide resistance profile relative to physicochemical properties of breeding habitats within Accra Metropolis, Ghana. Tanzan J Health Res. 2011;13:163-87.

3. Antonio-Nkondjio C, Fossog BT, Ndo C, Djantio BM, Togouet SZ, AwonoAmbene $\mathrm{P}$, et al. Anopheles gambiae distribution and insecticide resistance in the cities of Douala and Yaoundé (Cameroon): influence of urban agriculture and pollution. Malar J. 2011;10:154.

4. Mukhtar M, Herrel N, Amerasinghe FP, Ensink J, Van Der Hoek W, Konradsen F. Role of wastewater irrigation in mosquito breeding in south Punjab, Pakistan. Southeast Asian J Trop Med Public Health. 2003;34:72-80.

5. Gunathilaka N, Karunaraj P. Identification of sibling species status of Anopheles culicifacies breeding in polluted water bodies in Trincomalee district of Sri Lanka. Malar J. 2015;14:214.

6. Tene Fossog B, Kopya E, Ndo C, Menze-Djantio B, Costantini C, Njiokou F, et al. Water quality and Anopheles gambiae larval tolerance to pyrethroids in the cities of Douala and Yaoundé (Cameroon). J Trop. Med. 2012:2012:429817.

7. Sattler MA, Mtasiwa D, Kiama M, Premji Z, Tanner M, Killeen GF, et al. Habitat characterization and spatial distribution of Anopheles sp. mosquito larvae in Dar es Salaam (Tanzania) during an extended dry period. Malar J. 2005:4:4

8. El Sayed BB, Arnot DE, Mukhtar MM, Baraka OZ, Dafalla AA, Elnaiem DEA, et al. A study of the urban malaria transmission problem in Khartoum. Acta Trop. 2000;75:163-71.

9. Eltayeb GE. Urban slums reports: the case of Khartoum, Sudan. In: Understanding slums: Case studies for the global report on human settelments. London UCL, DPU, UN Habitat. 2003; p 20.

10. The Sudan population and housing census. 2008. ILO microdata repository. 
11. WHO. Malaria entomology and vector control: part 1: learner's guide. Geneva:WHO/CDS/CP; 2003. p. 69.

12. Gillies M, Coetzee M. A supplement to the anophelinae of Africa South of the Sahara. Publ South African Inst Med Res. 1987;55:63.

13. Scott JA, Brogdon WG, Collins FH. Identification of single specimens of the Anopheles gambiae complex by the polymerase chain reaction. Am J Trop Med Hyg. 1993;49:520-9.

14. Aboud M, Makhawi A, Verardi A, Raba'a F, Elnaiem D, Townson H. A genotypically distinct, melanic variant of Anopheles arabiensis in Sudan is associated with arid environments. Malar J. 2014;13:492.

15. WHO. Global plan for insecticide resistance management in malaria vectors (GPIRM). WHO/HTM/GMP/2012-5; Geneva: World Health Organization.

16. Finney DJ. Probit analysis: a statistical treatment of the sigmoid response curve. Oxford: Macmillan; 1947.

17. Trape JF, Lefebvre-Zante E, Legros F, Ndiaye G, Bouganali H, Druilhe P, et al. Vector density gradients and the epidemiology of urban malaria in Dakar, Senegal. Am J Trop Med Hyg. 1992;47:181-9.

18. Keiser J, Utzinger J, Caldas De Castro M, Smith TA, Tanner M, Singer BH. Urbanization in sub-Saharan Africa and implication for malaria control. Am J Trop Med Hyg. 2004;71:118-27.
19. Afrane YA, Klinkenberg E, Drechsel P, Owusu-Daaku K, Garms R, Kruppa T. Does irrigated urban agriculture influence the transmission of malaria in the city of Kumasi, Ghana? Acta Trop. 2004;89:125-34.

20. Elkhalifa SM, Mustafan IO, Wais M, Malik EM. Malaria control in an urban area: a success story from Khartoum, 1995-2004. Eastern Mediterr Health J. 2008;14:206-15.

21. Gimnig JE, Ombok M, Kamau L, Hawley WA. Characteristics of Larval Anopheline (Diptera: Culicidae) Habitats in Western Kenya. J Med Entomol. 2001;38:282-8.

22. Mutero CM, Ng'ang'a PN, Wekoyela P, Githure J, Konradsen F. Ammonium sulphate fertiliser increases larval populations of Anopheles arabiensis and culicine mosquitoes in rice fields. Acta Trop. 2004;89:187-92.

23. Fillinger U, Sonye G, Killeen GF, Knols BGJ, Becker N. The practical importance of permanent and semipermanent habitats for controlling aquatic stages of Anopheles gambiae sensu lato mosquitoes: operational observations from a rural town in western Kenya. Trop Med Int Health. 2004;9:1274-89.

24. Ndenga BA, Simbauni JA, Mbugi JP, Githeko AK. Physical, chemical and biological characteristics in habitats of high and low presence of Anopheline larvae in Western Kenya Highlands. PLoS ONE. 2012;7:e47975.
Ready to submit your research? Choose BMC and benefit from:

- fast, convenient online submission

- thorough peer review by experienced researchers in your field

- rapid publication on acceptance

- support for research data, including large and complex data types

- gold Open Access which fosters wider collaboration and increased citations

- maximum visibility for your research: over $100 \mathrm{M}$ website views per year

At BMC, research is always in progress.

Learn more biomedcentral.com/submissions 